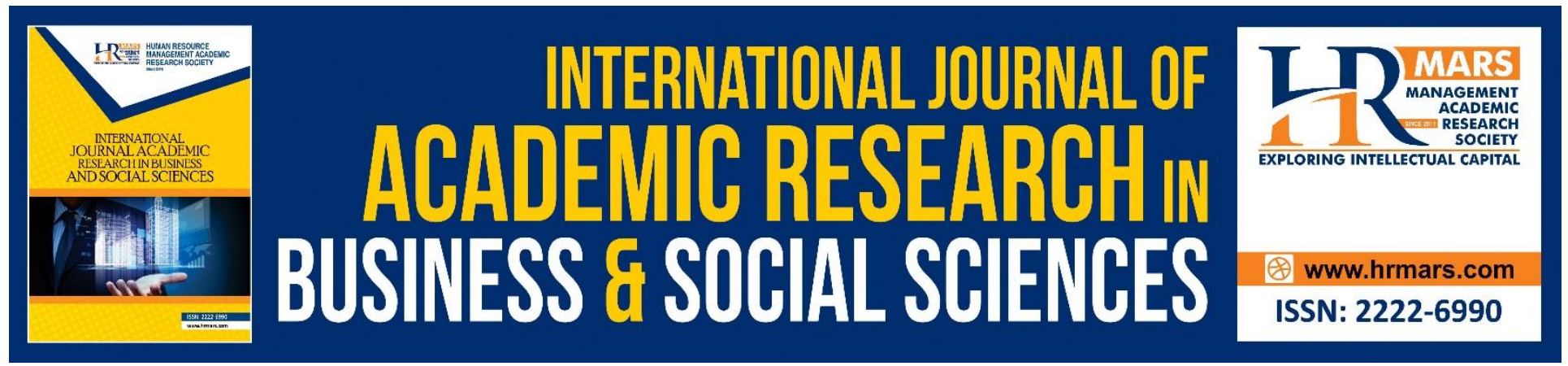

\title{
The Influence of Information Systems Application for Regional Financial Management, Human Resources Competency and Understanding of Government Accounting Standards on Regional Financial Management Performance of Aceh Besar Regency
}

Yoki Andrian, Hasan Basri and Yossi Diantimala

To Link this Article: http://dx.doi.org/10.6007/IJARBSS/v8-i9/4537

DOI: $\quad 10.6007 /$ IJARBSS/v8-i9/4537

Received: 29 June 2018, Revised: 07 August 2018, Accepted: 29 August 2018

Published Online: 20 September 2018

In-Text Citation: (Andrian, Basri, \& Diantimala, 2018)

To Cite this Article: Andrian, Y., Basri, H., \& Diantimala, Y. (2018). The Influence of Information Systems Application for Regional Financial Management, Human Resources Competency and Understanding Of Government Accounting Standards on Regional Financial Management Performance of Aceh Besar Regency. International Journal of Academic Research in Business and Social Sciences, 8(9), 1-13.

Copyright: (c) 2018 The Author(s)

Published by Human Resource Management Academic Research Society (www.hrmars.com)

This article is published under the Creative Commons Attribution (CC BY 4.0) license. Anyone may reproduce, distribute, translate and create derivative works of this article (for both commercial and non-commercial purposes), subject to full attribution to the original publication and authors. The full terms of this license may be seen

at: http://creativecommons.org/licences/by/4.0/legalcode

Vol. 8, No. 9, September 2018, Pg. 1 - 13

http://hrmars.com/index.php/pages/detail/IJARBSS

JOURNAL HOMEPAGE

Full Terms \& Conditions of access and use can be found at http://hrmars.com/index.php/pages/detail/publication-ethics 


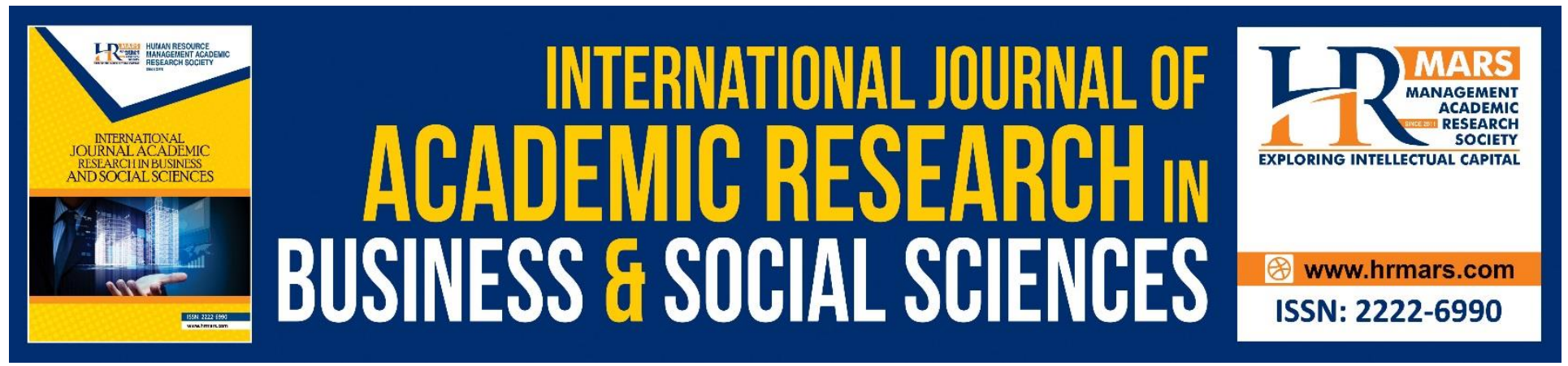

\title{
The Influence of Information Systems Application for Regional Financial Management, Human Resources Competency and Understanding Of Government Accounting Standards on Regional Financial Management Performance of Aceh Besar Regency
}

\author{
Yoki Andrian, Hasan Basri and Yossi Diantimala \\ Faculty of Economics and Business, Syiah Kuala University, Banda Aceh \\ Corresponding Author: yoki_andrian@yahoo.com
}

\begin{abstract}
The purpose of this study is to examine the influence of information systems application for regional financial management, human resources competency and understanding of government accounting standards on regional financial management performance of Aceh Besar regency. This research consist of 50 population of SKPD in Aceh Besar regency, with 150 respondents consisting of 50 Budget Users, 50 Financial Administration (PPK) officials and 50 Expenditure Treasurers as respondents. The data analysis method used in this research is multiple linear regression. The results of research both partially and simultaneously support the hypothesis and application of information systems for regional financial management, human resource competency, and understanding of government accounting standards affect the performance of financial management of Aceh Besar regency.
\end{abstract}

Keywords: Information System Application for Regional Financial Management, Human Resource Competency, Understanding of Government Accounting Standards, Performance of Regional Financial Management.

Introduction

The paradigm of local financial management has undergone a very fundamental change since the enactment of regional autonomy in 2001. With the enactment of Law No. 32 of 2004 on Regional Government and Law No. 33 of 2004 on Fiscal Balance between the Central Government and Local Government, which became the main basis in implementing regional autonomy in essence provides greater opportunities for the region to further optimize the potential of the region, whether concerning human resources, funds, or other resources which is the wealth of the region. With regional autonomy, the government is expected to become more independent, reducing dependence on the central government, both in terms of development financing and in terms of regional financial management. 
INTERNATIONAL JOURNAL OF ACADEMIC RESEARCH IN BUSINESS AND SOCIAL SCIENCES Vol. 8, No. 9, Sept. 2018, E-ISSN: 2222-6990 @ 2018 HRMARS

According to (Mardiasmo, 2009, p. 123), "Measurements of performance derived from financial information, such as financial statements, are measured based on the planned budget ." Therefore, the financial performance of local government becomes an important thing for local government and external parties. Financial performance is one measure that can be used to ensure regional capability in implementing good and proper financial implementation rules to maintain desired services, whereby higher valuations become demands to be met for external parties to decide to invest in the region.

However, regarding to the Circular Letter of the Ministry of Home Affairs of the Republic of Indonesia No. SE.900/122/BAKD about Technical Guidelines for implementation SIPDD and Regional SIPD, the main objective of SIPKD and Regional SIKD activities is to develop and implement local financial applications based on local needs and conditions with the prevailing local financial management system. Competence is the basis of a person to achieve high performance in completing its performance. Human resources that are not competent will not be able to complete their work efficiently, effectively and economically. As a concrete effort to realize transparency and accountability of local financial management is the delivery of accountability reports of government finance that meet the principles of timely and reliable and compiled by following generally accepted Government Accounting Standards (SAP).

This article aims to find the truth of the issues and problem raised by some media and even the results from BPK examination that the financial management of the local Government of Aceh Besar has been categorized well by giving the predicate unqualified opinion (WTP) four times in a row but with special notes. Researchers want to investigate where the biggest influence that resulted in the performance of local financial management is still constrained. Whether on the financial application systems that have not run smoothly, the competence of human resources as well as on knowledge of government accounting standards.

\section{Literature Review}

\section{The Performance of Local Financial Management}

Mahsun (2009) defines "Performance is a description for the level of achievement of the implementation over the activityies/programs/policies in realizing the goals, objectives, mission and vision of the organization contained in Strategic planning of an organization". Performance appraisal can be used to measure organizational activities in the achievement of goals and also as material for future improvement.

\section{Information System Application for Regional Financial Management (SIPKD)}

SIPKD is an application developed by the Directorate General of Regional Finance of The Ministry for Home Affair in order to accelerate data transfer and efficiency in the collection of local financial data. The SIPKD application is obtained by sub-directorate of Regional Financial Management Information at the Directorate of Regional Financial Implementation and Accountability.

Information system is a system within the organization that brings daily transaction processing needs, support operations, managerial and strategic activities of an organization and provide information such as parties with the reports required for decision making (Jogiyanto, 2010, p. 11). 
INTERNATIONAL JOURNAL OF ACADEMIC RESEARCH IN BUSINESS AND SOCIAL SCIENCES

Vol. 8, No. 9, Sept. 2018, E-ISSN: 2222-6990 @ 2018 HRMARS

\section{Human Resources Competency}

Human Resources is the unity of human labor in the organization and it is not just the sum of the existing employees. Human resources is a very important organizational element, therefore it must be ensured that human resources must be managed as well as possible to contribute optimally in an effort to achieve organizational goals.

Human resources is the main supporting pillar as well as drive the organization in an effort to realize the vision and mission and the purpose of the organization (Wiley, 2002).

\section{Understanding of Government Accounting Standard}

SAP is the accounting principles adopted in preparing and presenting government financial statements. Government Accounting Standards established by the government through Government Regulation No. 71 of 2010 is one of the government's efforts in meeting the various needs that appear in accounting financial reporting both central government and local government. Understanding according Poerwadarminta (2006) in Indonesian General Dictionary is the process, the way, the act of knowing or understanding.

According to (the Government Accounting Committee, 2005, p. 6) states that "SAP is the accounting principles applied in preparing and presenting the government's financial statements". Thus, SAP is a requirement that has the power of law in an effort to improve the quality of government financial statements in Indonesia.

The Effect of Information System Application for Regional Financial Management on Performance of Regional Financial Management

A good financial management system is key to realizing good governance in the public sector. This means that the better the implementation of SIPKD, the better the performance of the financial management of the region itself. The importance of improving the performance of computerized local financial management based on international best practical. Research using the variable of Regional Financial Information System has been done by Yuliani (2009, p. 12), concludes that with the implementation of financial information systems in the process of preparing financial reports will produce quality information.

\section{The Effect of Human Resources Competency on Performance of Regional Financial Management} Human resources is the most important factor in the successful performance of regional financial management implementation, for it needs a continuous effort to improve human resource capabilities in line with the changes that occur. According to Hersey and Blanchart $(1992$, p. 5) in the journal Human Resource Management there are three areas of ability required to carry out the work process: Technical and technical skills, social skills, conceptual abilities and conseptual skills.

\section{The Effect of Understanding Government Accounting Standard on Performance of Regional Financial Management}

Local governments should totally improve the performance of regional management as a form of autonomy provided by the Central Government. For that purpose, the main focus by local governments is the presentation of more transparent, accountable and efficient financial statements. Certainly required a standard in the preparation of financial statements in order to provide optimal results. 
INTERNATIONAL JOURNAL OF ACADEMIC RESEARCH IN BUSINESS AND SOCIAL SCIENCES Vol. 8, No. 9, Sept. 2018, E-ISSN: 2222-6990 (c) 2018 HRMARS

A study using Government Accounting Standard (SAP) once performed by Simon (2010), the result of the previous study states that the successful implementation of auditing accounting standards in local financial management can result in a more transparent and more accountable, for that reason it needs more effort from many parties.

\section{Hypothesis}

In accordance with the background, problem formulation, research objectives, theoretical views and framework above hypothesis testing can be formulated as follows:

H1: Information systems application for regional financial management, human resources competency and understanding of government accounting standards have a positive effect on performance of regional financial management of Aceh Besar regency.

H2: Information systems application for regional financial management has a positive effect on performance of regional financial management of Aceh Besar regency.

H3: Human resources competency has a positive effect on performance of regional financial management of Aceh Besar regency.

$\mathrm{H} 4$ : Understanding of government accounting standards has a positive effect on performance of regional financial management of Aceh Besar regency.

\section{Research Method}

\section{Research Population}

This research is a quantitative research using census method by making the whole population as research object (Sugiyono, 2004). This study is a census study, the population in this study is the officials involved directly in the process of budgeting, the Local Work Unit (SKPD) of 50 SKPD. Each SKPD consists of 3 people who will be the respondent, namely: Head of Service as Budget User (PA), Secretary or Head of Section as SKPD Administration Official (PPK-SKPD), SKPD Treasurer. There are 150 people in the study as a respondent.

This study is a case study by trying to examine the effect of local financial management information systems, human resources competency and understanding of government accounting standards on the performance of local financial management, by examining the answers of government apparatus to the questions posed regarding statement statement in this research. This study is a field study, where the scope of the study is natural with minimum intervention.

The data source which used in this research is primary data, it is a data that directly collected by the researcher. The data gather from the structural questionnaire which refer to previous study by Indriasari \& Naharyo (2008) and elaborated by the researcher. The questionnaires are directly accepted to the respondent such as Head of Service as Budget User (PA), Secretary or Head of Section as SKPD Administration Official (PPK-SKPD), SKPD Treasurer. For each questionnaire will have score from 1 to 5 regarding to level of their understanding.

\section{Variable Operationalization}

This study tested the hypothesis to determine the effect of independent variables on the dependent variable. In this research, Information System Application for Regional Financial Management (X1), Human Resource Competency (X2) and Understanding of Government Accounting Standard (X3) on Performance of Regional Financial Management (Y) as independent variable. 


\section{Variable Operationalization}

\begin{tabular}{|c|c|c|c|}
\hline $\begin{array}{l}\text { Type of } \\
\text { Variable }\end{array}$ & Operational Definition & Indicator & Scale \\
\hline $\begin{array}{l}\text { Performanc } \\
\text { e of } \\
\text { Regional } \\
\text { Financial } \\
\text { Manageme } \\
\text { nt } \\
\text { (Y) }\end{array}$ & $\begin{array}{l}\text { Using Measurable quality } \\
\text { and quantity. } \\
\text { (Financial Management } \\
\text { Improvement } \\
\text { Committee, 2006) }\end{array}$ & $\begin{array}{l}\text { State Adiminstration } \\
\text { Agency of the Republic } \\
\text { of Indonesia (2003) }\end{array}$ & Interval \\
\hline $\begin{array}{l}\text { Implement } \\
\text { ation of } \\
\text { SIPKD } \\
\left(X_{1}\right)\end{array}$ & $\begin{array}{l}\text { The application of } \\
\text { financial information } \\
\text { system is the utilization of } \\
\text { financial information } \\
\text { system (documenting, } \\
\text { administering, financial } \\
\text { processing and } \\
\text { management data and } \\
\text { other data) into } \\
\text { information presented to } \\
\text { the community and as } \\
\text { decision making materials } \\
\text { in the framework of } \\
\text { planning, and } \\
\text { implementation } \\
\text { reporting of government } \\
\text { accountability (PP. No. } 56 \\
\text { year 2005) }\end{array}$ & $\begin{array}{l}\text { - Understanding } \\
\text { Application } \\
\text { - Procedures } \\
\text { - Data } \\
\text { - Software } \\
\text { - Information System } \\
\text { Infrasctruture } \\
\text { (Romney, 2006, p. 3) } \\
\end{array}$ & Interval \\
\hline $\begin{array}{l}\text { Human } \\
\text { Resources } \\
\text { Competenc } \\
\text { y } \quad\left(X_{2}\right)\end{array}$ & $\begin{array}{l}\text { Resources capable of } \\
\text { creating not only } \\
\text { comparative values, but } \\
\text { also innovative- } \\
\text { generative-innovative } \\
\text { copolymers using the } \\
\text { highest energy such as } \\
\text { intellegence, creativity } \\
\text { and imagination, no } \\
\text { longer merely use raw } \\
\text { energy such as raw } \\
\text { materials, land, water, } \\
\text { muscle energy, etc. } \\
\text { (Ndraha, 1997, p. 12) }\end{array}$ & $\begin{array}{l}\text { - Position Description } \\
\text { - Education } \\
\text { Background } \\
\text { - Training and } \\
\text { Workshop } \\
\text { - Skills } \\
\text { (Indriasari \& Naharyo, } \\
\text { 2008) }\end{array}$ & Interval \\
\hline
\end{tabular}


INTERNATIONAL JOURNAL OF ACADEMIC RESEARCH IN BUSINESS AND SOCIAL SCIENCES Vol. 8, No. 9, Sept. 2018, E-ISSN: 2222-6990 @ 2018 HRMARS

\begin{tabular}{|c|c|c|c|}
\hline $\begin{array}{l}\text { Understand } \\
\text { ing of } \\
\text { Governmen } \\
t \\
\text { Accounting } \\
\text { Standard } \\
\qquad\left(X_{3}\right)\end{array}$ & $\begin{array}{l}\text { Understanding of } \\
\text { accounting principles } \\
\text { applied in preparing and } \\
\text { presenting government } \\
\text { financial statements } \\
\text { (Government rules No. } 71 \\
\text { year 2010) }\end{array}$ & $\begin{array}{l}\text { - Understanding the } \\
\text { basic of accounting } \\
\text { - Understanding of } \\
\text { historical cost } \\
\text { - Understanding of } \\
\text { realization principle } \\
\text { - Understanding the } \\
\text { substance above } \\
\text { formality } \\
\text { - Understanding } \\
\text { periodic principle } \\
\text { (PSAP No } 1 \text { about } \\
\text { presenting the } \\
\text { financial report) }\end{array}$ & Interval \\
\hline
\end{tabular}

The analysis method used in this research is multiple regression analysis, which is used to measure the relationship between the dependent variable and the independent variable collectively and individually.

The regression equation model can be formulated as follows:

Description:

$$
Y=\alpha+\beta_{1} X_{1}+\beta_{2} X_{2}+\beta_{3} X_{3}+\varepsilon
$$

$\mathrm{Y} \quad=$ Performance of Regional Financial Management

$\alpha \quad=$ Constant

$\beta_{1,2,3}=$ Regression Coefficient

$\varepsilon=$ Error

$\mathrm{X}_{1}=$ Information System Application for Regional Financial Management

$\mathrm{X}_{2}=$ Human Resources Competency

$\mathrm{X}_{3} \quad=$ Understanding of Government Accounting Standard

\section{Research Result and Discussion}

Regarding to the 114 questionnaires distributed to the respondents it has been returned to the researcher, where the rate of return in this study is $100 \%$. The results of hypothesis testing using SPSS can be seen in Table 2 . 
INTERNATIONAL JOURNAL OF ACADEMIC RESEARCH IN BUSINESS AND SOCIAL SCIENCES Vol. 8, No. 9, Sept. 2018, E-ISSN: 2222-6990 @ 2018 HRMARS

Table 2

\begin{tabular}{|l|r|c|}
\hline \multirow{2}{*}{\multicolumn{1}{|c|}{ Variable }} & \multicolumn{2}{c|}{$\begin{array}{c}\text { Unstandardized } \\
\text { Coefficients }\end{array}$} \\
\cline { 2 - 3 } & B & $\begin{array}{c}\text { Std. } \\
\text { Error }\end{array}$ \\
\hline (Constant) & 1,211 & 0,282 \\
\hline $\begin{array}{l}\text { Information System of Regional } \\
\text { Financial Management (X1) }\end{array}$ & 0,115 & 0,061 \\
\hline Human Resource Competency (X2) & 0,474 & 0,065 \\
\hline Government Accounting Standard (X3) & 0,198 & 0,077 \\
\hline $\begin{array}{l}\text { Correlation Coefficient } \\
\text { Determination Coefficient }\end{array}$ & 0,855 \\
Adjust R Squared & 0,731 \\
$=$ & 0,720 \\
\hline
\end{tabular}

Regarding to the results of statistical calculations using SPSS program as stated in Table 2, then obtained the multiple linier regression equation as follows:

$$
Y=1,211+0,115 X_{1}+0,474 X_{2}+0,198 X_{3}+\text { eror }
$$

The result of the regression equation can be seen that the influence of information system of regional financial management is equal to 0.115 . the correlation coefficient $(R)$ of 0.855 indicates that the degree of correlation between independent variables and dependent variable is $85.5 \%$. it infers the relationship of Local Financial Management System (X1), Human Resource Competency (X2) and Understanding of Government Accounting Standard (X3) on Performance of Financial Management $(\mathrm{Y})$ is a strongly positive linear relationship.

The coefficient of determination $\left(R^{2}\right)$ of 0.731 means that the Performance of Financial Management $(Y)$ is influenced by the Information System Application for Regional Financial Management (X1), Human Resource Competency (X2) and Understanding of Government Accounting Standard (X3) of $73.1 \%$, while $26.9 \%$ influenced by other variables not included in this study.

The constant value of 1.211 indicates that if the variable of the Information System Application for Regional Financial Management (X1), Human Resource Competency (X2) and Understanding of Government Accounting Standards (X3) is equal to zero, then the performance of Financial Management (Y) in SKPD Aceh Besar regency is 1,211 units of interval scale.

The result of Hypothesis Testing using Simultaneous and Partial Test

The influence of information systems application for regional financial management, human resources competency and understanding of government accounting standards on performance of regional financial management

The results of regression testing for the first hypothesis in this study was conducted to determine the information system application for regional financial management, human resource competency, and Government Accounting Standards affect simultaneously to the performance of regional financial management. The results of the test find the value of regression coefficient $(\beta)$ of each variable is 0.115 for variable information system application for regional financial management 
INTERNATIONAL JOURNAL OF ACADEMIC RESEARCH IN BUSINESS AND SOCIAL SCIENCES Vol. 8, No. 9, Sept. 2018, E-ISSN: 2222-6990 @ 2018 HRMARS

( $\beta 1)$ 0.474 for variable of human resource competency ( $\beta 2)$, and 0,198 for Government Accounting Standard variable $(\beta 3)$.

The hypothesis determines if there is at least one $\beta i \neq 0(i=1,2,3,4)$ : Ha is accepted, meaning that the information system application for regional financial management, Human Resource Competency, and Government Accounting Standards have a mutual influence on the Performance of regional financial management. The result of the research concludes that the information system application for regional financial management, human resource competency, and government accounting standard influence to the performance of regional financial management because the regression coefficient of the three variables is greater than 0 with the coefficient of determination (R2) of 0.855 . This means that the Information System Application for Regional Financial Management, Human Resource Competency, and Government Accounting Standards are able to explain the variation of the variable Performance of regional financial management by $85.5 \%$ while the remaining $14.5 \%$ is explained by other variables not included in this research variable.

\section{The influence of information systems application for regional financial management on performance of regional financial management}

The results of regression testing for the second hypothesis in this study was conducted to determine whether the Regional financial information management system affect the performance of regional financial management. The test results show the value of regression coefficient $(\beta 1)$ for variable Local financial management information system is 0.115 . Determination of the hypothesis says if $\beta 1 \neq 0$ : Ha accepted, meaning that the information system of local financial management influence on the performance of local financial management.

\section{The influence of human resources competency on performance of regional financial management}

The result of regression testing for the third hypothesis in this study was conducted to determine whether the competence of human resources has an effect on the performance of financial management area. The test result shows the value of regression coefficient ( $\beta 2)$ for the variable of human resources competence is 0.474 . Determination of the hypothesis says if $\beta 2 \neq 0$ : Ha accepted, meaning that the competence of human resources affect the performance of local financial management.

\section{The influence of understanding of government accounting standards on performance of regional financial management}

Regression test results for the fourth hypothesis in this study was conducted to determine whether the Government Accounting Standards affect the performance of local financial management. The test result shows the value of regression coefficient ( $\beta 3$ ) for Government Accounting Standard variable is 0,198 . Determination of the hypothesis says if $\beta 3 \neq 0$ : Ha accepted, meaning that the Government Accounting Standards affect the performance of local financial management.

The result of Wati, Herawati, and Sinarwati research (2014), on the Influence of Human Resource Competency, SAP Application and Regional Financial Accounting System to the Quality of Regional Financial Statement, shows that the competence of human resources has a positive and significant impact on the quality of local financial statements, the application of government accounting standards has a positive and significant impact on the quality of local financial report, 
INTERNATIONAL JOURNAL OF ACADEMIC RESEARCH IN BUSINESS AND SOCIAL SCIENCES Vol. 8, No. 9, Sept. 2018, E-ISSN: 2222-6990 @ 2018 HRMARS

regional financial accounting system have a positive and significant impact on the quality of local financial statements, and competence of human resources, the application of government accounting standards, financial accounting system has significant effect on the quality of financial statements.

\section{Conclusion and Suggestion}

Information system application for regional financial management, human resources competency and implementation of government accounting standard have an effect collectively to performance of financial management in Aceh Besar Regency. It is clearly found that the better the implementation of information systems of regional financial manegement, human resource competency and understanding of government accounting standards, the better the performance of financial management achieved every SKPD.

Implementation of information systems local financial management partially positive effect on the performance of financial manager SKPD in Aceh Besar Regency. This indicates that the better the regional financial management information system is applied, the better the performance of SKPD's financial manager in Aceh Besar Regency.

Competence of human resources partially have a positive effect on to the performance of SKPD financial manager in Aceh Besar Regency. This indicates that the better the competence of human resources as financial manager of SKPD, the better the performance of financial manager of SKPD in Aceh Besar Regency.

Understanding of government accounting standards partially positively affect the performance of financial manager SKPD in Aceh Besar District. This indicates that the better the level of understanding apparatus as financial manager of SKPD, the better the performance of SKPD financial manager in Aceh Besar District.

Of the three dependent variables, the variable X1 or the application of financial management information systems areas that have the greatest influence on improving the performance of financial managers in the district of Aceh Besar.

Nevertheless, this research has some limitations such as it is only conducted on one district/city and the variables used are only 3 (three) variables. Therefore, for the next researcher can expand the research subjects to all ministries/agencies/local government agencies in Indonesia and add other variables that affect the performance of financial managers such as leadership factors, organizational commitment, work climate, workload, and socialization. For policy makers to support the improvement of competence of human resources related to the management of regional finances, encourage the regional financial management apparatus in implementing and completing their main tasks and functions, placing human resources according to capacity and specialization according to the needs of the organization, and periodically evaluating on the value of reward and punishment related to the management of regional finances in Aceh Besar Regency.

\section{References}

Badan Pemeriksa Keuangan Republik Indonesia. (2007). Peraturan Badan Pemeriksa Keuangan Republik Indonesia No 1 Tahun 2007 tentang Standar Pemeriksaan Keuangan Negara. Bandung: Fokusmedia.

Badan Pemeriksa Keuangan Republik Indonesia. (2014). Undang-Undang No. 15 tahun 2004 tentang Pemeriksaan Pengelolaan dan Tanggung Jawab Keuangan Negara, Jakarta. (Law no. 15 of 
INTERNATIONAL JOURNAL OF ACADEMIC RESEARCH IN BUSINESS AND SOCIAL SCIENCES Vol. 8, No. 9, Sept. 2018, E-ISSN: 2222-6990 @ 2018 HRMARS

2004 on Audit of Management and Responsibility of State Finance, Jakarta). Badan Pemeriksa Keuangan Republik Indonesia. Diakses dari http://www.bpk.go.id/assets/files/storage/2013/12/file storage 1386158654.pdf.

Bastian, I. (2006). Akuntansi Sektor Publik: Suatu Pengantar (Public Sector Accounting: An Introduction). Jakarta: Erlangga.

Bungin, B. (2011). Metodologi Penelitian Kuantitatif (Quantitative Research Methodology). Jakarta: Kencana.

Dessler, G. (2009). Manajemen Sumber Daya Manusia (Human Resource Management). Jakarta: Indeks.

Halim, A. (2003). Auditing I Dasar-Dasar Audit Laporan Keuangan (Auditing I Audit Basics Financial Statements). Yogyakarta: Unit Penerbit dan Percetakan AMP YKPN.

Hutapea, P. \& Nurianna, T. (2008). Kompetensi Plus (Plus Competencies). Jakarta: PT. Gramedia Pustaka Utama.

Kemendagri. (2008). Peraturan Menteri Dalam Negeri Republik Indonesia Nomor 4 Tahun 2008 Tentang Pedoman Pelaksanaan Reviu Atas Laporan Keuangan Pemerintah Daerah. (Regulation of the Minister of Home Affairs of the Republic of Indonesia Number 4 Year 2008 on Guidelines for Implementation of Review on Local Government Financial Statements). Direktorat Jenderal Bina Keuangan Daerah Kementerian Dalam Negeri. Diakses dari http://keuda.kemendagri.go.id/produkhukum/download/180/permendagri-no-04-tahun2008.

Kemendagri. (2010). Peraturan Pemerintah Nomor 65 Tahun 2010 tentang Sistem Informasi Keuangan Daerah. (Government Regulation Number 65 Year 2010 regarding Regional Financial Information System). Direktorat Jenderal Bina Keuangan Daerah Kementerian Dalam Negeri. Diakses dari keuda.kemendagri.go.id/produkhukum/download/506/pp-no-65-tahun2010.

Kemendagri. (2011). Permendagri Nomor 21 Tahun 2011 Tentang Pedoman Pengelolaan keuangan Daerah (Permendagri Number 21 of 2011 About the Guidelines of Regional Financial Management). JDIH Surabaya. Diakses dari https://jdih.surabaya.go.id/pdfdoc/permendagri 58.pdf.

Kementrian Keuangan. (2000). Peraturan Pemerintah Republik Indonesia No. 105 Tahun 2000 Tentang Pengelolaan dan Pertanggungjawaban Keuangan Daerah. (Government Regulation of the Republic of Indonesia No. 105 of 2000 on the Management and Accountability of Regional Finance). Direktorat Jenderal Perimbangan Keuangan. Diakses dari http://www.djpk.depkeu.go.id/attach/post-no-105-tahun-2000-tentang-pengelolaan-danpertanggungjawaban-keuangan-daerah/--259-294-PP105 2000.pdf. 
INTERNATIONAL JOURNAL OF ACADEMIC RESEARCH IN BUSINESS AND SOCIAL SCIENCES

Vol. 8, No. 9, Sept. 2018, E-ISSN: 2222-6990 @ 2018 HRMARS

Kementrian Keuangan. (2005). Peraturan Pemerintah Republik Indonesia Nomor 58 Tahun 2005 tentang Pengelolaan Keuangan Daerah. (Government Regulation No. 58/2005 on Regional Financial Management). Direktorat Jenderal Perimbangan Keuangan. Diakses dari http://www.djpk.depkeu.go.id/attach/post-no-58-tahun-2005-tentang-pengelolaankeuangan-daerah/--376-490-PP58 2005.pdf.

Kementrian Keuangan. (2006). Peraturan Pemerintah Republik Indonesia Nomor 8 Tahun 2006 tentang Pelaporan Keuangan dan Kinerja Instansi Pemerintah. (Government Regulation No. 8/2006 on Financial Reporting and Performance of Government Agencies). Direktorat Jenderal Perimbangan Keuangan. Diakses dari http://www.djpk.depkeu.go.id/attach/post-pp-no-8tahun-2006-tetang-pelaporan-keuangan-dan-kinerja-instansipemerintah/PP82006LAKIP.pdf.

Kementrian Keuangan. (2010). Peraturan Pemerintah Republik Indonesia No. 71 Tahun 2010 tentang Standar Akuntansi Pemerintahan. (Government Regulation of the Republic of Indonesia No. 71 Year 2010 on Government Accounting Standards). Direktorat Jenderal Perimbangan Keuangan. Diakses dari http://www.djpk.depkeu.go.id/attach/post-pp-no-71-tahun-2010tentang-standar-akuntansi-pemerintahan/PP71.pdf.

Kothari, C. R. (2004). Research Methodology: Methods and Techniques. (2nd Rev. ed). New Delhi: New Age International Publisher.

Mahmudi. (2013). Manajemen Kinerja Sektor Publik. (Public Sector Performance Management). (Edisi Kedua). Jakarta: LPPSTIM YKPN.

Mahoney, T. A., Jerdee, T. H., \& Carroll, S. J. (1963). Development of Managerial Performance: A Research Approach. Cincinnati: South Western Publ. Co.

Mahsun, M. (2009). Pengukuran Kinerja Sektor Publik (Public Sector Performance Measurement). Yogyakarta: BPFE.

Mangkunegara, A. P. (2006). Evaluasi kinerja Sumber Daya Manusia (Evaluation of Human Resource Performance). Jakarta: Refika Aditama.

Mardiasmo. (2009). Akuntansi Sektor Publik (Public Sector Accounting). Yogyakarta: Penerbit Andi.

Martindas, R. (2002). Manajemen Sumber Daya Manusia, Lewat Konsep Ambisi, Kenyataan dan Usaha. (Management of Human Resources, Through The Concept of Ambition, Reality and Effort Part II). (Edisi II). Jakarta: Grafiti.

Mulyadi. (2001). Sistem Akuntansi (Accounting System Third Edition). (Edisi Ketiga). Jakarta: Salemba Empat.

Pirade, D., Saleh, A. K., \& Amar, M. Y. (2013). The Influence of The Use of Regional Financial Management Information System On Officials Performance in Regional Government of Tana 
INTERNATIONAL JOURNAL OF ACADEMIC RESEARCH IN BUSINESS AND SOCIAL SCIENCES

Vol. 8, No. 9, Sept. 2018, E-ISSN: 2222-6990 @ 2018 HRMARS

Toraja

Regency.

Diakses

dari

pasca.unhas.ac.id/jurnal/files/c693b49ae0e96ec7f5c4f13a64e74ec9.pdf.

Poerwadarminta. (2006). Kamus Lengkap Bahasa Indonesia (Full Dictionary of Indonesian Language). Jakarta: Balai Pustaka.

Romney, M. B. \& Steinbart, P. J. (2006). Sistem Informasi Akuntansi (Accounting Information System). Jakarta: Salemba Empat.

Sekaran, U. (2011). Metode Penelitian Untuk Bisnis (Research Methods For Business). (Edisi 4). Jakarta: Salemba Empat.

Simon, E. (2010). Pengaruh Penerapan Standar Akuntansi Pemerintahan dan Peran Auditor BPK-RI terhadap pengelolaan Keuangan Daerah pada Satuan Kerja Perangkat Daerah Pemerintahan Kota Banda Aceh. (Thesis). Pascasarjana Universitas Syiah Kuala Banda Aceh.

Sudjana. (2005). Metode Statistika (Statistics Method). Bandung: Tarsito.

Sugiyono. (2016). Metode Penelitian Kuantitatif, Kualitatif, dan R\&D (Quantitative, Qualitative, and $R \& D$ Research Methods). Bandung: Alfabeta.

Suharto, A. A. (2012). Pengaruh Kualitas Sumber Daya Manusia, Komitmen dan Motivasi terhadap Kinerja pegawai pada Inspektorat Kabupaten Kediri. Jurnal IImu Manajemen, Revitalisasi, 1(3), 72.

Sumarsono, S. (2003). Ekonomi Manajemen Sumber Daya manusia dan Ketenagakerjaan. (Economics of Human Resource Management and Employment). Yogyakarta: Graha Ilmu.

Wati, K. D., Herawati, N. T., \& Sinarwati, N. K. (2014). Pengaruh Kompentensi SDM, Penerapan SAP dan Sistem Akuntansi Keuangan Daerah Terhadap Kualitas Laporan Keuangan Daerah.(Effect of Human Resources Competency, Application of SAP and Regional Financial Accounting System to Quality of Local Financial Report). e-Journal Universitas Pendidikan Ganesha Jurusan Akuntansi Program S1, 2, (1), 1. 